\title{
IMPROVEMENT OF MC SI SOLAR CELLS BY AL-GETTERING AND HYDROGEN PASSIVATION
}

\author{
G. Hahn, W. Jooss, M. Spiegel, P. Fath, G. Willeke, E. Bucher, \\ University of Konstanz, Faculty of Physics, P.O. Box X916, D-78457 Konstanz, Germany
}

\begin{abstract}
Systematic Al-gettering and MIRHP (Microwave Induced Remote Hydrogen Plasma) passivation studies have been carried out on various ribbon (EFG, Bayer RGS) and multicrystalline (mc) Si materials (Baysix, Eurosil, Solarex, EMC) with initial minority carrier diffusion lengths varying from $<30-300 \mu \mathrm{m}$. Gettering was investigated between $700-1050^{\circ} \mathrm{C}$. Solar cells with optimized Algettering conditions including a selective emitter structure were characterized before and after MIRHP passivation in order to separate the benefits of gettering and hydrogen passivation. We could achieve improvements for most materials by Al-gettering and an increase in all cell parameters for all materials by MIRHP passivation, with an increase in efficiency for the ribbon Si materials of up to $30 \%$ relative.
\end{abstract}

\section{INTRODUCTION}

At present the largest part of the solar cell production is based on cast $\mathrm{mc} \mathrm{Si}$. This is due to higher costs and the shortage of monocrystalline Si wafers which show better performance parameters. In the last years a lot of effort was made to improve the quality of $\mathrm{mc} S \mathrm{Si}$ using different techniques such as various gettering processes and hydrogen passivation $[1,2]$. With the employment of these techniques efficiencies of up to $18.6 \%$ could be reached on a $1 \times 1 \mathrm{~cm}^{2}$ Crystal Systems HEM mc Si solar cell [3]. The next step in reducing the costs for solar cell production could be the use of even cheaper ribbon Si. These materials have in common that no losses due to wafer cutting from large ingots occur, less expense for the wafer production is needed and a high throughput is expected. Because of the even lower Si quality of these materials $[4,5]$ (crystal defects, purity, oxygen content) as compared to cast $\mathrm{mc} \mathrm{Si}$ the use of the techniques mentioned above is again very important to improve $\mathrm{J}_{\mathrm{sc}}$, $V_{o c}$ and thus the cell efficiencies. Ribbon Si solar cell performance is lower than that of cast mc Si in most cases but the cheaper wafer production should overcompensate this disadvantage. Thus ribbon $\mathrm{Si}$ is an economically attractive alternative to standard cast $\mathrm{Si}$. This study was carried out in order to find the optimum Al-gettering and hydrogen passivation for ribbon and cast mc Si materials manufactured with different methods.

\section{USED MATERIALS}

In our study we have chosen seven mc Si materials from differing manufacturing processes. Baysix, Eurosil P43 and P48 and Solarex are all standard, EMC is an electromagnetically cast $\mathrm{mc} \mathrm{Si}$ whereas EFG (Edgedefined Film-fed Grown) and Bayer RGS (Ribbon Growth on Substrate) are ribbon Si. Due to the different manufacturing methods the $\mathrm{Si}$ materials show large differences in the minority charge carrier diffusion length $L_{\text {diff. }}$ In Table 1 the approximate $L_{\text {diff }}$ of the source materials before processing as determined by SPV (Surface PhotoVoltage) measurements can be found. As expected $L_{\text {diff }}$ shows the lowest values for the ribbon $\mathrm{Si}$ materials because of impurities and a high oxygen concentration present especially in RGS [5].

Table 1. Approximate minority charge carrier diffusion length $L_{\text {diff }}$ for the materials used in this study before processing as determined by SPV measurements.

\begin{tabular}{|l|c|}
\hline Material & approx. Ldiff $_{\text {dy SPV }}$ [um] \\
\hline Baysix & 130 \\
\hline Eurosil P43 & 120 \\
\hline Eurosil P48 & $>150$ \\
\hline Solarex & $<100$ \\
\hline EMC & 100 \\
\hline EFG & $<80$ \\
\hline RGS & $<30$ \\
\hline
\end{tabular}

For our study we used neighboring $5 \times 5 \mathrm{~cm}^{2}$ wafers with the same crystal grain structure in the case of the cast $\mathrm{mc} \mathrm{Si}$ in order to be able to compare the four $2 \times 2 \mathrm{~cm}^{2}$ cells prepared from these wafers after processing. For the selection of EFG material we took neighboring wafers from one EFG tube.

\section{AL-GETTERING STUDY}

In the first part of our study we investigated the impact of the Al-gettering temperature on the cell parameters, especially on $J_{s c}$ and $V_{o c}$. In Fig. 1 the applied solar cell process for the gettering study is shown schematically. A leveling of the ribbon Si with a conventional wafer dicing saw was done to be able to use photolithography. $2 \mu \mathrm{m}$ of $\mathrm{Al}$ were evaporated and a gettering step of $30 \mathrm{~min}$ at temperatures between $700-1050^{\circ} \mathrm{C}$ under $\mathrm{N}_{2}$ atmosphere was applied. In Fig. 2 Al-gettering results for Eurosil P48 


\begin{tabular}{c}
\hline Leveling (EFG and RGS) \\
Defect etching \\
POCls emitter diffusion \\
Al evaporation 2 $\mu \mathrm{m}$ \\
\hline Al gettering 30 min \\
\hline Photolithography \\
\hline TiPd/Ag front contact \\
\hline Al back contact \\
\hline Sintering \\
\hline
\end{tabular}

Fig. 1. Process sequence for the Al-gettering study.

are presented. The four different symbols represent the four cells with a different crystal grain structure. We could demonstrate improvements in both $J_{s c}$ and $V_{o c}$ resulting in an optimal Al-gettering temperature of about 900 $1000^{\circ} \mathrm{C}$

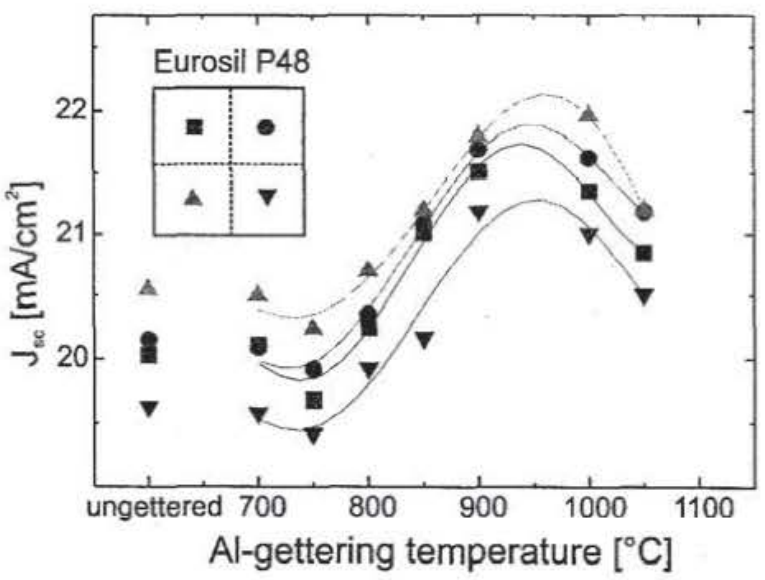

Fig. 2. Al-gettering results for Eurosil P48. The four symbols represent the four $2 \times 2 \mathrm{~cm}^{2}$ cells from one $5 \times 5 \mathrm{~cm}^{2}$ wafer with the same grain structure.

In order to prove that the increase in $\mathrm{J}_{s o}$ is combined with an increase in $L_{\text {diff }}$ we carried out spectral response measurements and fitted the obtained results in the long wavelength region with two dimensional computer simulations as described in [6]. Table 2 shows the results for the ungettered reference cell and the Al-gettered cells with the same grain structure. $L_{\text {diff }}$ is increased by $20 \mu \mathrm{m}$ for a gettering temperature of $950^{\circ} \mathrm{C}$ which is in agreement with the results of Fig. 2 .

Table 3 provides an overview for all materials and their optimum Al-gettering temperature $T_{\text {opt. }}$. For Solarex material a decrease in Ldiff could be observed, whereas Baysix and Eurosil P43 showed nearly identical diffusion lengths with or without an Al-gettering step. In the other materials $L_{\text {diff }}$ can be significantly increased by an Algettering step at the optimum temperature $T_{\text {opt }}$ shown.
Table 2. Ldiff for ungettered and Al-gettered cells of Eurosil P48 as fitted by computer simulations on spectral response data.

\begin{tabular}{|c|c|}
\hline Al-gettering temperature & $\mathrm{L}_{\text {diff }}[\mu \mathrm{m}]$ \\
\hline ungettered & 160 \\
\hline 700 & 130 \\
\hline 750 & 125 \\
\hline 800 & 143 \\
\hline 850 & 160 \\
\hline 900 & 162 \\
\hline 950 & 180 \\
\hline 1000 & 170 \\
\hline 1050 & 145 \\
\hline
\end{tabular}

Table 3. Comparison of $L_{\text {diff }}$ for ungettered reference cells and Al-gettered cells at the optimum temperature $\mathrm{T}_{\text {opt }}$ as determined by fitting of spectral response data.

\begin{tabular}{|l|c|c|c|}
\hline Material & ungettered & \multicolumn{2}{|c|}{ gettered } \\
\hline & $L_{\text {diff }}[\mu \mathrm{m}]$ & $\mathrm{T}_{\text {opt }}\left[{ }^{\circ} \mathrm{C}\right]$ & $L_{\text {diff }}[\mu \mathrm{m}]$ \\
\hline Baysix & 110 & 850 & 105 \\
\hline Eurosolare P43 & 130 & 900 & 135 \\
\hline Eurosolare P48 & 160 & 950 & 180 \\
\hline Solarex & 90 & 800 & 70 \\
\hline EMC & 100 & 850 & 130 \\
\hline EFG & 20 & 900 & 75 \\
\hline RGS & $<20$ & 700 & 20 \\
\hline
\end{tabular}

\section{HYDROGEN PASSIVATION STUDY}

Apart from gettering techniques the passivation of crystal defects like grain boundaries and dislocations by hydrogen is a further option to improve the cell parameters. Different authors report on benefiting hydrogen treatments for EFG [7], RGS and Eurosil [8]. In our study we used a MIRHP (Microwave Induced Remote

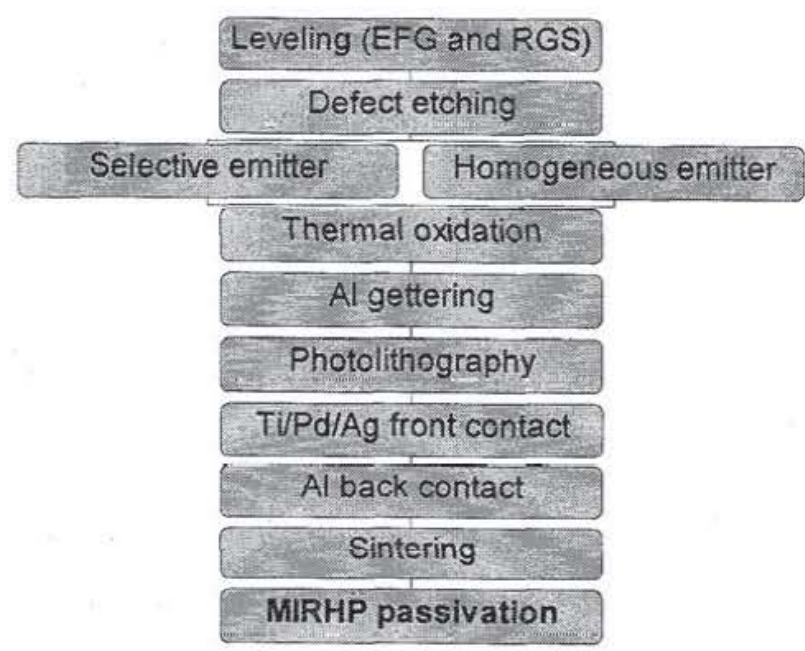

Fig. 3. Process sequence for the MIRHP passivation study 
Hydrogen Plasma) passivation technique presented in [8].

For separating the benefit from Al-gettering and MIRHP passivation, our solar cell process was modified in a second study as shown in Fig. 3 .

In order to compare the influence of a selective and a homogeneous emitter on the solar cell parameters during passivation, the samples were split and both emitter structures were processed. This time a thermal oxide was formed on the cell surface in order to be sure to just investigate the bulk passivation effect. We used the optimum Al-gettering temperature for each of the seven materials as obtained in the first study. The MIRHP passivation was carried out as the last step after cell metallization. In this way it was possible to characterize the Al-gettered cells prior to and after MIRHP passivation in order to get information about the improvement resulting from the hydrogen passivation step.

\section{MIRHP passivation - Results}

In the following results are presented which are all based on solar cells including a selective emitter structure unless otherwise stated. In Fig. 4 spectral response data for a Baysix solar cell before and after MIRHP passivation are shown. The absolute IQE is again fitted by computer simulations to extract $L_{\text {diff. }} A$ large increase in $L_{\text {diff }}$ after the passivation can be seen resulting in a gain in $\mathrm{J}_{\mathrm{sc}}$ of $1.0 \mathrm{~mA} / \mathrm{cm}^{2}$.

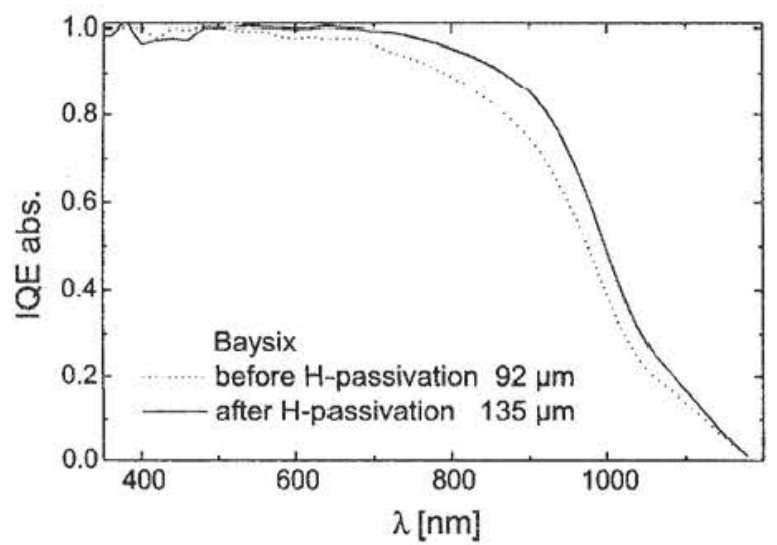

Fig. 4. Spectral response data for a Baysix solar cell before and after MIRHP passivation.

An even more dramatic effect was observed in the ribbon materials. Fig. 5 provides an example for an EFG solar cell before and after MIRHP passivation. An increase in Ldiff of $83 \mu \mathrm{m}$ has been observed which translates into a gain in $\mathrm{J}_{\mathrm{sc}}$ of $3.8 \mathrm{~mA} / \mathrm{cm}^{2}$.

The aim of this study was to find the optimum passivation time for all materials, therefore we measured the cells every 30 minutes during passivation. The gain in efficiency for all materials can be seen in Fig. 6 . improvements in all cell parameters were observed for all materials and the efficiency $\eta$ could be increased up to $30 \%$ relative in the case of the ribbon materials.

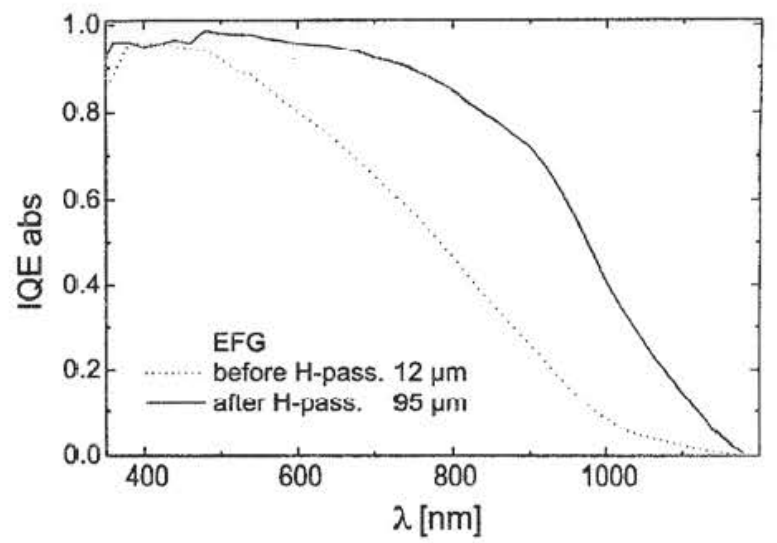

Fig. 5. Spectral response data for an EFG solar cell before and after MIRHP passivation.

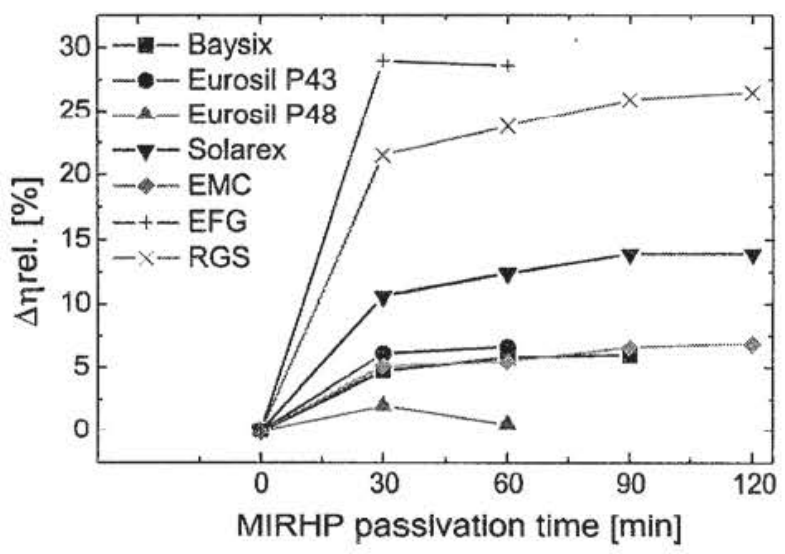

Fig. 6: Relative gain in efficiency for all used materials during MIRHP passivation.

A similar behavior was found for $V_{o c}$. We obtained an increase in $\mathrm{V}_{o c}$ of $35-40 \mathrm{mV}$ for the ribbon $\mathrm{Si}$ materials, but also all the other materials showed a significant effect.

Up to now all presented results were obtained with the selective emitter structure. While we saw the same behavior of $J_{s c}$ and $V_{o c}$ during the MIRHP passivation when comparing the selective and the homogeneous emitter structure, a distinct difference in fill factor dependence was observed. Fig. 7 shows the change in fill factor during the passivation of the homogeneous emitter structure. During the first 30 minutes of the passivation we could see the same increase as for the selective emitter structure, but for longer passivation times a clear decrease has been found. This decrease which cannot be observed for the selective emitter structure in this distinctness causes a loss in efficiency for longer MIRHP passivation times. This is in agreement with former experiments $[8,9]$.

In Table 4 the MIRHP passivation results are summarized. Given are the relative and absolute gains in efficiency $\Delta \eta_{\text {rel }}$ and $\Delta \eta_{\text {abs }}$ for the optimum MIRHP passivation time topt. We have improvements for all materials but again an especially good increase for the ribbon Si materials of nearly $30 \%$ relative. 


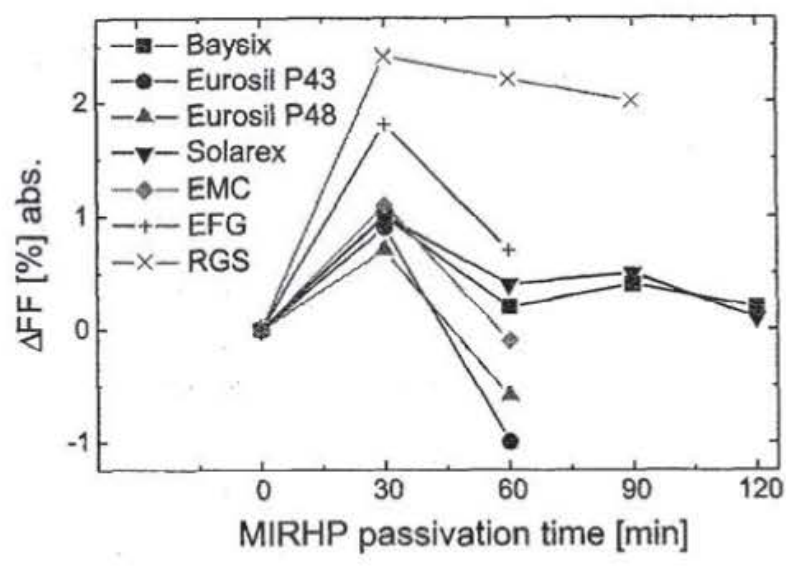

Fig. 7. Behavior of the fill factor during MIRHP passivation for the homogeneous emitter structure.

Table 4. Improvements in efficiency for all used materials at the optimum MIRHP passivation time topt.

\begin{tabular}{|l|c|c|c|}
\hline Material & MIRHP Pass. & \multicolumn{2}{|c|}{ selective emitter } \\
\hline & $t_{\text {opt }}[\mathrm{min}]$ & $\Delta \eta_{\text {rol }}[\%]$ & $\Delta \eta_{\text {abs }}[\%]$ \\
\hline Baysix & 90 & 6 & 0.6 \\
\hline Eurosil P43 & 30 & 7 & 0.6 \\
\hline Eurosil P48 & 30 & 2 & 0.2 \\
\hline Solarex & 120 & 14 & 1.2 \\
\hline EMC & 120 & 7 & 0.7 \\
\hline EFG & 30 & 29 & 2.1 \\
\hline RGS & 120 & 27 & 1.5 \\
\hline
\end{tabular}

\section{FUTURE PLANS}

Our future activities will include the combination of an additional mechanical V-texturing step with the optimal Al-gettering temperature and the MIRHP hydrogen passivation. First results on Bayer RGS show an efficiency of $11.1 \%$ (including DARC). This is yet without using the optimal Al-gettering temperature, so we look forward to improve this result soon.

\section{CONCLUSIONS}

The behavior of seven cast $\mathrm{mc}$ and ribbon Si materials has been investigated in two studies. In the first Algettering study we found the optimum gettering temperature for all materials. While a decrease in Loiff was seen in Solarex material and no improvements found in Baysix and Eurosil P43, all other materials showed a marked increase. Especially the efficiency of the ribbon Si materials could be improved.

The second MIRHP hydrogen passivation study delivered the optimum passivation times for all materials. Improvements in all cell parameters for all materials could be observed. EFG and Bayer RGS showed the highest gains in efficiency of up to $30 \%$ relative. The homogeneous emitter structure gave the same results during the first 30 minutes of the passivation, but a significant decrease in fill factor was observed for longer passivation times.

\section{ACKNOWLEDGEMENTS}

We would like to thank M. Keil for technical assistance during solar cell processing. This work was supported by the German BMBF under contract number 0329557A and within the JOULE program of the European Commission under contract number JOR3-CT95-0030.

\section{REFERENCES}

[1] S. Narayanan, S. R. Wenham, M. A. Green, Appl. Phys. Lett. 48, 1986, 873

[2] L. A. Verhoef, P.-P. Michiels, W. C. Sinke, C. M. M. Denisse, M. Hendriks, R. J.C. van Zollingen, Appl. Phys. Lett. 57, 1990, 2704

[3] A. Rohatgi, S. Narasimha, S. Kamra, P. Doshi, C. P. Khattak, K. Emery, H. Field, Proc. $25^{\text {th }}$ IEEE PVSC, 1996, 741

[4] J. P. Kalejs, J. Crystal Growth 128, 1993, 298

[5] G. Hahn, M. Spiegel, S. Keller, A. Boueke, P. Fath, G. Willeke, E. Bucher, Proc, $14^{\text {th }}$ EC PVSEC, 1997, in print

[6] C. Zechner, P. Fath, G. Willeke, E. Bucher, Proc. $14^{\text {th }}$ EC PVSEC, 1997, in print

[7] P. Sana, A. Rohatgi, J. P. Kalejs, R. O. Bell, Appl. Phys. Lett. 64, 1994, 97

[8] M. Spiegel, P. Fath, K. Peter, B. Buck, G. Willeke, E. Bucher, Proc. $13^{\text {th }}$ EC PVSEC, 1995, 421

[9] M. Spiegel, S. Keller, P. Fath, G. Willeke, E. Bucher, Proc. $14^{\text {th }}$ EC PVSEC, 1997, in print 